\title{
Research
}

\section{Understanding Household Connectivity and Resilience in Marginal Rural Communities through Social Network Analysis in the Village of Habu, Botswana}

\author{
$\underline{\text { Lin Cassidy }}^{1}$ and $\underline{\text { Grenville D. Barnes }}^{2}$
}

\begin{abstract}
Adaptability is emerging as a key issue not only in the climate change debate but in the general area of sustainable development. In this context, we examine the link between household resilience and connectivity in a rural community in Botswana. We see resilience and vulnerability as the positive and negative dimensions of adaptability. Poor, marginal rural communities confronted with the vagaries of climate change, will need to become more resilient if they are to survive and thrive. We define resilience as the capacity of a social-ecological system to cope with shocks such as droughts or economic crises without changing its fundamental identity. We make use of three different indices of household resilience: livelihood diversity, wealth, and a comprehensive resilience index based on a combination of human, financial, physical, social, and natural capital. Then, we measure the social connectivity of households through a whole network approach in social network analysis, using two measures of network centrality (degree centrality and betweenness). We hypothesize that households with greater social connectivity have greater resilience, and analyze a community in rural Botswana to uncover how different households make use of social networks to deal with shocks such as human illness and death, crop damage, and livestock disease. We surveyed the entire community of Habu using a structured questionnaire that focused on livelihood strategies and social networks. We found that gender, age of household head, and household size were positively correlated with social connectivity. Our analysis indicates that those households that are more socially networked are likely to have a wider range of livelihood strategies, greater levels of other forms of social capital, and greater overall capital. Therefore, they are more resilient.
\end{abstract}

Key Words: adaptive capacity; capital; household connectivity; household resilience; social networks

\section{INTRODUCTION}

Resilience has emerged as an insightful framework for studying complex, dynamic human-environment interactions (see, for example, Berkes and Folke 1998, Carpenter et al. 2001, Gunderson and Holling 2002, Anderies et al. 2006). Resilience "stresses the importance of assuming change and explaining stability, instead of assuming stability and explaining change" (Folke et al. 2003). A resilience approach recognizes that there is no single stable state in a socialecological system (SES), but that the system is exposed to different "shocks" that challenge its fundamental identity and make it dynamic. Therefore, resilient systems have the adaptive capacity or coping mechanisms to absorb shocks and adapt to new challenges without changing their fundamental structure and function (Alcorn and Toledo 1998, Gunderson and Holling 2002). In SESs such as rural communities, this capacity in turn relies on the community's capacity for social learning and innovation (Walker and Salt 2006). The exact definition of adaptive capacity and how it relates to resilience varies among resilience scholars. In some instances, resilience is seen as a subcomponent of adaptive capacity (Brooks and Adger 2005), whereas others regard it as a process that modifies ecological resilience (Gunderson 2000). The definition often depends on whether a scholar focuses predominantly on the social system (former) or ecological system (latter). This assessment concurs with that of Adger et al. (2004):

\section{... the term "adaptive capacity" is used to cover a multitude of factors, but there is no general agreement as to what these factors should be. Neither is there much in the published literature regarding the relationship between vulnerability and adaptive capacity; the former is described variously as the inverse or as a function of the latter.}

As a result, resilience and adaptive capacity are often used interchangeably. Here, we see adaptive capacity as a key factor that contributes to resilience and is largely related to the nature of social institutions and networks.

Increasingly, attention is being paid to human vulnerability and how to reduce this through strengthening social resilience (Adger 2000, Nelson et al. 2007). Redundancy of social institutions or resources and social or ecological diversity/ heterogeneity contribute to system resilience (Bodin et al. 2006) through enhancing its adaptive capacity. Adaptive capacity is also impacted by a system's internal and external connectivity which is activated through various networks,

${ }^{1}$ Okavango Research Institute, University of Botswana, ${ }^{2}$ School of Forest Resources and Conservation, University of Florida 
whether physical (e.g., road networks), social, economic, or ecological. Gunderson and Holling (2002) define "connectedness" as the "strength of internal connections that mediate the influences between inside processes and the outside world." Therefore, connectivity is closely linked to resilience, although this may be a complex relationship depending on the nature of the shock and the network metrics used to analyze it (Janssen et al. 2006). We use social network analysis to explore the relationship between connectivity and resilience.

Here, we have focused on households in a community in rural Botswana that is relatively isolated, being $2.5 \mathrm{hrs}$ by vehicle from the district capital of Maun in Ngamiland and $20 \mathrm{~km}$ from the nearest asphalt road. Drawing on Blaikie (1994) and Heijmans (2004), we assume that households with greater amounts of key types of "capital" are more resilient, and hence less vulnerable to shocks. We also expect households that are more connected, both directly and indirectly, to be more resilient (Adger 2003). A large proportion of Botswana's population is rural, and in the country's semi-arid but highly variable environment, households follow a range of primarily natural resource-based livelihood strategies as a way of limiting their vulnerability to shocks and stresses. This has been shown for San remote area dweller settlements Kalahari (Sallu et al. 2010) as well as in the Okavango Delta (Kgathi et al. 2007, Wilk and Kgathi 2007).

\section{Vulnerability and Resilience}

The relationship between vulnerability and resilience has long been debated (see, for example, Manyena 2006). Although we recognize that the concepts are not simply antonyms of each other, it is clear that they generally have an inverse relationship. The resilience of a SES, such as a rural community, does not necessarily mean all components, i.e., households, have the same degree of resilience. Importantly, “...resilient individuals may exist in non-resilient systems and resilient systems may contain individuals who are not resilient" (Manyena 2006). Here, we use resilience to mean the ability of a social unit, in this case the household unit, to adapt to environmental change and cope with external and internal shocks. Conversely, vulnerability is interpreted as susceptibility to shocks and reduced adaptive capacity (Busby et al. 2010).

We also build on work from the disaster risk-reduction community that emphasizes the local, community-based level (Thomalla et al. 2006). Central characteristics of a disasterresilient community are organization and structures for information exchange (Twigg 2007). However, although formal institutions have a critical role to play in ensuring full awareness, informal and family networks of exchange are equally important, particularly for households with limited resources (Dershem and Gzirishvili 1998, Hoddinott et al., unpublished manuscript).
It is important to note that development studies, in their interpretation of the concept of resilience, sometimes fail to acknowledge scale effects. There may be ethical reasons for not applying the ecological usage, where resilience is based on a system's ability to change its components, while still maintaining its overall structure (Holling 2001). If losing some households is a way for a community structure to stay resilient, then it is clear that from a moral standpoint that it is not only on the emergent property of community that we must focus, but also on the constituent elements of individual people or households. Therefore, we structure our conceptual approach on ideas such as the Household Vulnerability Index (Food, Agriculture and Natural Resources Policy Analysis Network 2006) and the Human Adaptive Capacity Index (Vincent 2007) which measure the range and amounts of different types of capital available to households, and which are seen as contributing towards resilience and sustainable livelihoods (Ellis 2000). The levels of capital gauge the size of buffer that households have against shocks such as drought and disease (see, for example, Kgathi et al. 2007, and Sallu et al. 2010), and can be used to indicate the ability of a household to respond to, and persist through, shocks (Fig. 1).

Fig. 1. Schematic diagram showing the five types of household capital that contribute to household adaptive capacity and resilience.

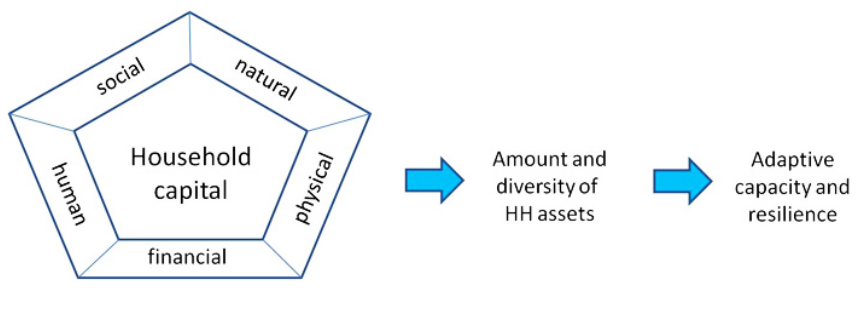

\section{Social Networks and Resilience}

In the same way that capital can be seen as contributing to resilience, we believe that social networks represent a form of connectivity that correlates with resilience. Social network analysis is attracting increasing attention as a tool for measuring social connectivity that arises through exchanges in information, labor, money, and food (Hanneman and Riddle 2005, Webb and Bodin 2008). The role of social networks for sharing information and knowledge on natural resources, and particularly the adaptive management of these resources to promote resilience, has previously been illuminated by several different authors, including Crona and Bodin (2006), Janssen et al. (2006), and Olsson et al. (2004). Adger (2003) argued that "many aspects of adaptive capacity reside in the networks and social capital of the groups that are likely to be affected [by climate change]." The "bonding ties" that connect members of a group are recognized as being important for 
enhancing resilience by facilitating the internal transmission of information and knowledge (Putnam 2001). On the other hand, "bridging ties," the external connections to different groups, are important for promoting innovation as these are more likely to bring new ideas into their group.

Here, we are particularly interested in analyzing informal networks as organizations that explain variations in how vulnerable rural households deal with external and internal stresses and shocks. Although resilience has proved to be a useful framework for studying linked social-ecological systems, it is extremely challenging to reach cross-disciplinary agreement on key resilience indicators (Janssen et al. 2006). We contend that an analysis of social networks within a community provides valuable insights into the adaptive capacity of more resilient households.

Social networks are typically analyzed by looking at their structure, that is, relationships between respondents and network members or "alters," and composition, that is, attributes of the respondents (McCarty et al. 2007). In their work on adaptive management of natural resources, Bodin et al. (2006) analyzed network structure by focusing on "degree centrality" and "betweenness." Degree centrality is simply the number of other nodes, being households in our case, that are directly connected to a specific node. A high degree centrality can enhance resilience by providing redundancy and facilitating social learning, and can be an indicator of high levels of trust. Degree centrality is an effective way of measuring how integrated a node is (Valente and Foreman 1998). Betweenness measures the indirect connectivity of each node (household) by computing the number of times a specific node is part of the shortest path between all others pairs of nodes. High betweenness across the broader network can also add redundancy and facilitate social learning in the community (Fig. 2). However, nodes with exceptionally high betweenness may also be sources of vulnerability to the whole network if their removal significantly reduces the interconnectivity of subgroups in the network. Generally, betweenness assesses a broader level of connection, linking different subnetworks, that may allow diversity in connections, and hence the ability to be influenced by different subnetworks or environments (Brass 1984, Goh et al. 2003).

Fig. 2. How social network structure impacts resilience and vulnerability.

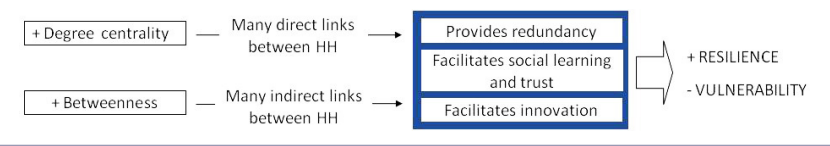

\section{Study Area}

As with much of the southern African region, the southern Okavango has been identified as vulnerable to climate change and climate variability (Regional Climate Change Programme 2009, Bauer and Scholz 2010). Such variability highlights the need for high adaptive capacity, particularly in small rural communities where livelihoods are primarily based on natural resources (Shackleton et al. 2001, Twyman 2001, Shackleton and Shackleton 2006, Kgathi et al. 2007, Wilk and Kgathi 2007). Here, we focus on Habu, a small rural village lying on the south-western periphery of the Okavango Delta (Fig. 3). Unlike those few rural communities that fall within wildlife management areas (see, for example, Blaikie 2004, and Mbaiwa et al. 2011), remote villages in tribal grazing areas such as Habu do not have access to the wildlife-based community projects that are major earners and hence buffers against unpredictable rainfall and flooding. In addition, much of the attention in the recent past has been on those few communities that can either use wildlife hunting and tourism as a key source of livelihood (so-called CBNRM communities) or belong to a minority that is discriminated against (e.g., San; see, for example, Sallu et al. 2009, and Sallu et al. 2010). By focusing on a community outside of a wildlife management area, we not only depict conditions that are more representative of broader rural Botswana, but also can better represent variation between households. In this way, we hope to highlight the utility of the resilience-connectivity framework in understanding social change and vulnerability, which are key aspects of climate variability research.

Habu comprises a residential core surrounded by outlying cattle posts (Fig. 3). The last census, in 2001, recorded 70 households comprising a total of 304 people (Central Statistics Office 2002). However, since that time, there has been steady population growth, and the current population has more than doubled. The village lies on the distal end of the Thaoge River, one of the drier, seasonally flooded river channels of the Okavango. This area is characterized by thornveld savanna on alluvial sands, with patches of fertile soils associated with the floodplains of the Thaoge River (Bendsen and Gelmroth 1983). According to community members, the first settlers in the area were of Bushmen origin, who maintained a somewhat nomadic lifestyle. By the 1800s, a few Yei families, part of the migration from what is now Namibia's Caprivi Strip (Tlou 1976), had settled there. Fields began to be regularly ploughed on the fertile floodplains in the late 1960s. In 1970, Herero households arrived in the area. There is still a strong cultural difference in livelihood strategies, with Yei, who are increasingly assimilated into Tswana culture and adopt that language, focusing primarily on crop production, and Herero focusing mainly on livestock. 
Fig. 3. Location and structure of Habu village, showing scattered cattleposts up to $10 \mathrm{~km}$ away from the village core.

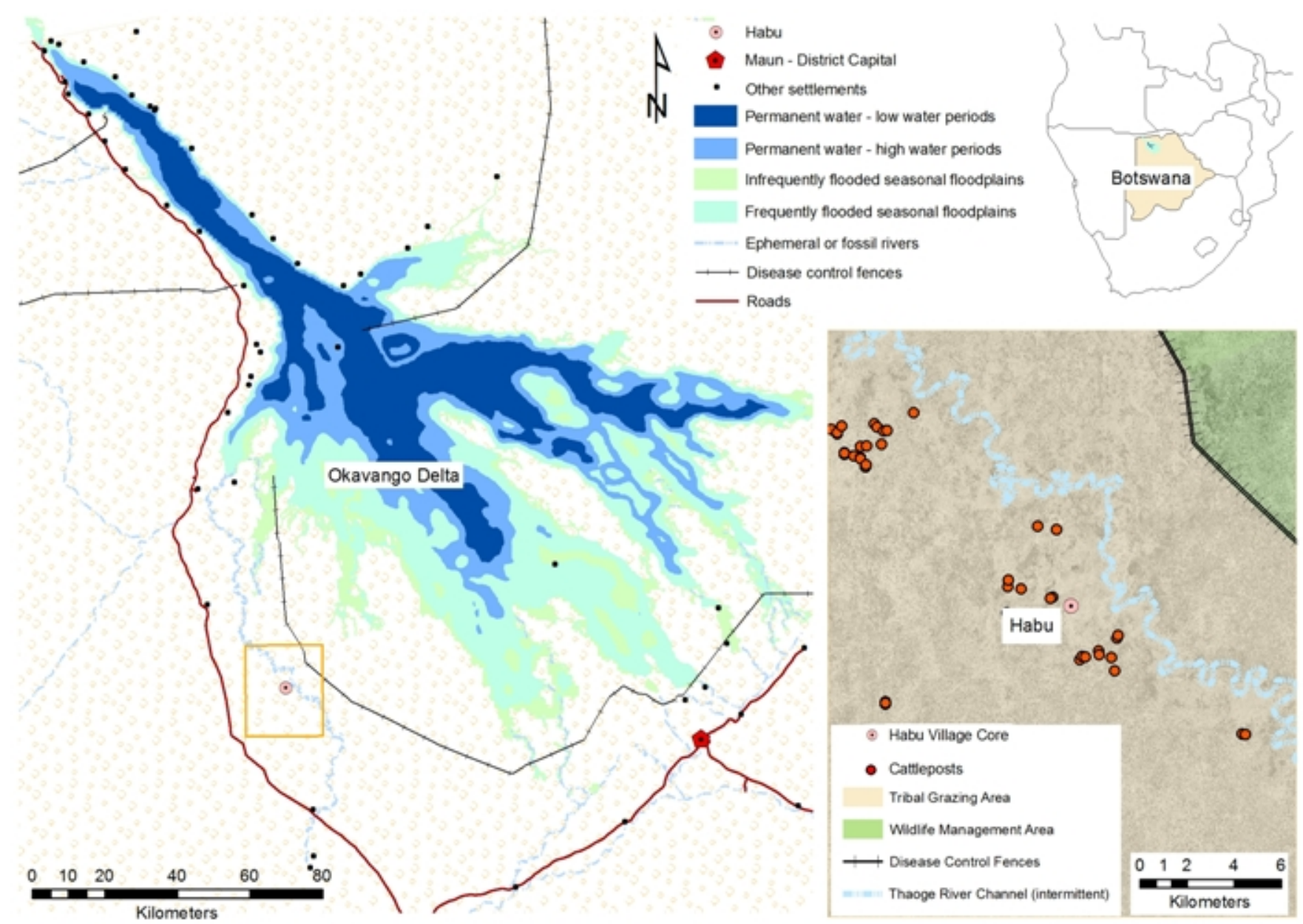

Note: Darker shades in the inset map indicate scrub and woodland, whereas lighter shades show old floodplains dominated by grassland.

Because of its remoteness, Habu appears to have limited connection to outside markets, and households rely on natural resources, both for the dominant agricultural activities mentioned above and directly for building materials including branches for poles, mud for walls, and thatching grass for roofs, and for medicinal and food plants. This remoteness and reliance on natural resources puts the community at risk from environmental variability and shocks, and community members recount a series of such events which have challenged them over the past 50 years.

Habu lies on communally-held tribal land. The village gained official settlement status in 1979, with an appointed headman of arbitration. However, since national independence in 1966, the responsibilities and powers of village level headmen have steadily been eroded to be replaced with a more centralized governance structure. This centralization has resulted in increasing open access as customary land is now open to any citizen of Botswana (Cassidy 2000). Although two legal systems co-exist in Botswana, there is an understanding that subsistence levels of use fall under customary law and are governed at the community level, whereas higher levels of resource extraction relating to commercial use fall under common law, and are subject to the regulations set out in Botswana's statutes (Cassidy 2000). Because Habu is situated some distance from other settlements, there is little opportunity for commercial harvesting of natural resources, and thus the role of the headman has remained relatively strong.

The tribal land on which the Okavango and its surroundings lie has further been zoned into three categories: protected areas comprised of parks and game reserves, wildlife management areas, and tribal grazing areas (Cassidy 2000). Habu lies on 
tribal grazing land, and is separated from the adjacent wildlife management area by a livestock disease control fence (Fig. 3). There is a health clinic in the village, but the nearest doctor is in the village of Nokaneng, some $50 \mathrm{~km}$ away by road, and the nearest hospital is in the district capital, Maun. All young children attend primary school in Habu. The nearest secondary school is in Tsau, also about $50 \mathrm{~km}$ away. This is where most children attend as weekly boarders, although some also go to school in communities where households have relatives.

\section{METHODS}

We used focus groups to understand the specific types of shocks that had been experienced by the community and to identify issues around which people in Habu might need to interact. Focus-group discussions, especially those disaggregated on gender lines, are effective tools in helping outsiders understand issues that are critical to community members (Slocum et al. 1998). In these focus-group discussions, involving approximately 75 community members including 30 men and 45 women, participants compiled timelines of the development of the settlement and identified major events or shocks that had occurred during this time. The three primary shocks identified were livestock disease, crop damage, and human disease and death. Based on these discussions, we examined exchanges undertaken in times of such shocks across four different networks: information, labor, food, and money.

A quantitative survey of 145 households, which represents approximately $80 \%$ of all households based in Habu, was conducted to collect basic demographic and livelihood data and lists of other households with whom the interviewed household engaged in various exchanges. The intention to capture all households proved logistically unfeasible, as some $20 \%$ of households were entirely absent during the 3-week survey period. Therefore, for the purpose of this analysis, we treat the 145 households as representing our full population and internal network, and interactions with any of the other $20 \%$ of households are treated the same as those with households living in neighboring settlements.

Because the household is the livelihood unit of shared production and consumption in Habu, as well as more generally in Botswana, this is also the unit of vulnerability or resilience in terms of shocks to livelihoods. When faced with an external shock or perturbation, responses to the shock are likely to vary more between households than within households (for example, Sallu et al. 2010). This assumption is supported by the sustainable livelihoods literature and related development programs (see for example, Carney et al. 1999, Ellis 2000, Scoones 1998). We further believe that by testing social network analysis at this aggregated level, we will inform this field of study with regard to social exchanges at a level beyond that of the individual (cf. Lhotka et al. 2008).
In keeping with the vulnerability and community resilience literature (Food, Agriculture and Natural Resources Policy Analysis Network 2006, Twigg 2007) and similar work elsewhere in communities around the Okavango (Kgathi et al. 2007), we structure our analysis along the five different forms of capital identified as important to sustainable livelihoods: financial, physical, natural, human, and social. Social support and safety-net schemes such as labor-based public works and orphan relief are considered part of the "transforming structures and processes" and not as a "livelihood asset" (cf. Carney et al. 1999) and, therefore, are not included in our analyses of capital. Indicators of resilience and adaptive capacity, based on these forms of capital, are assessed against social network indices relating to four pathways of connectivity between households: the exchange of information, labor, food, and money. This connectivity is analyzed both separately for each of these four exchange types, as well as for overall exchanges for each household.

We use three calculated indices to represent household resilience: 1) a Livelihood Diversity Index, which is a simple summation of the number of different strategies, rather than their relative contribution, that each household follows to build up its economy (Fig. 4), 2) a Wealth Index (Fig. 4), which pulls together the range of physical and financial capital and assigns relative order-of-magnitude values based on current market values to each measure, and 3) a Resilience Index, which adds in weighted social, human and natural capital measures to the financial and physical capitals (See Fig. 4 and Fig. 5). For each index, values are standardized by assessing each household's value as a proportion of the total summed values for the community. The three measures were identified for assessment because wealth and diversity of livelihoods have been shown to influence adaptive capacity and resilience (Chambers and Conway 1992, Ellis 2000, Perz 2005, Morton 2007, Vincent 2007, Pacheco 2009), in the same way that the theoretical concepts of diversity and relative abundance and redundancy strengthen complex adaptive systems (Holland

Fig. 4. Schematic diagram showing the analytical approach used to assess the relationship between connectivity and different measures of resilience.

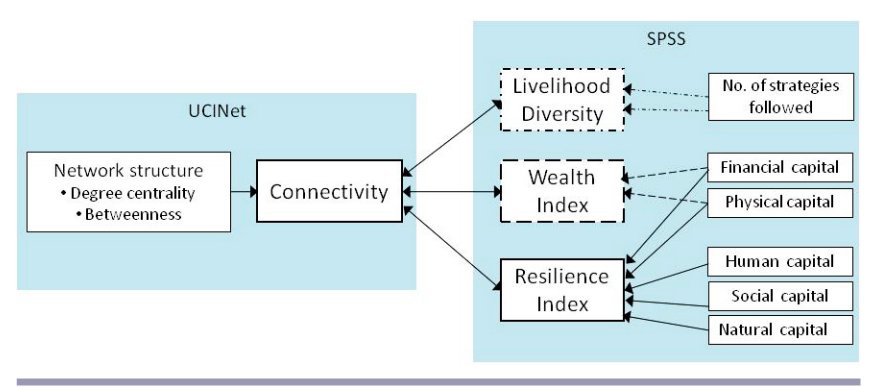


1995, Levin 1999) through offering opportunity for reorganization and renewal (Folke et al. 2003). It is noted that other indices of well-being exist, such as the UNDP's Human Development Index (Sagar and Najam 1998) and the proposed National Well-being Index (Vemuri and Costanza 2006) as well as a Livelihood Vulnerability Index (Hahn et al. 2009). However, the former tend to capture community or national level patterns by drawing on aggregations of household information, whereas the latter, while also evaluating at household level and drawing on the sustainable livelihoods approach, does not build into the resilience and connectivity framework, and also includes social networks, which could lead to circular dependencies in analyses against connectivity. Therefore, we believe that the three indices used here are more suitable for evaluating system resilience, because they speak directly to the key complex adaptive system concepts of diversity and adaptive capacity (Twyman 2001, Perz 2005, Vincent 2007, Pacheco 2009).

To represent connectivity, we focus on two key social network metrics: degree centrality and betweenness, as described above and shown in Fig. 2. We used UCINET software for the social network analysis in this research (Borgatti et al. 2002). UCINET was developed by social network analysis scholars, and has become the most utilized software package for such analyses. All interviewed households in Habu were asked to name three other households with whom they exchanged information, labor, food, or money in times of stress. A link between two households means that at least one of the households listed the other as a household with whom they exchanged information, labor, food or money. To maintain confidentiality, household names were removed, and replaced with a code number ranging from 1001 to 1145 . SPSS v19 was used to assess variation in the different indices of resilience and to evaluate the correlations between connectivity and the resilience indices (Fig. 4). Because the connectivity and resilience data are index values and not from a probability distribution, non-parametric tests were run.

\section{RESULTS}

\section{Variation in Key Indicators of Household Capitals}

There is considerable variation in the distribution of the different types of capital across the Habu community. Looking first at financial capital, less than half $(43.8 \%)$ of households had one or more members in full-time employment. Nearly all of these jobs were outside of Habu village, meaning the person did not permanently reside in the household dwelling. There are a range of small business activities that households engage in across the year, typically on an ad hoc basis. These are related to housing construction and maintenance, and the production of tools and household products. On average, households earn some money from two different small businesses, but $25 \%$ of households have no such source of income. The main activity that people received money from
Fig. 5. List and weighting of indicators used to calculate the household resilience index, based on Vincent's Household Adaptive Capacity Index (2007).

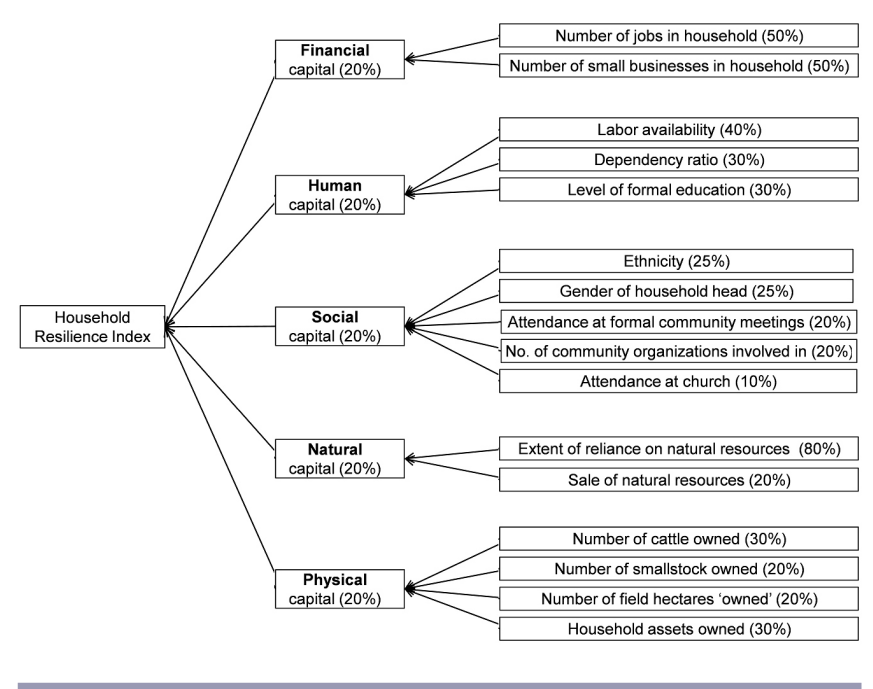

was through the sale of livestock and livestock products ( $40.7 \%$ of households).

Turning to physical capital, the distribution of cattle ownership is extremely skewed. $27 \%$ of households had fewer than six cattle, the minimum number needed for plowing, whereas $14.5 \%$ of households had $>100$ head each. This is similar for smallstock, which are sheep and goats combined. $50 \%$ of households had $<20$ smallstock, whereas only $7.6 \%$ of households had $>100$. Note that this is partly explained by ethnic differences. The Herero are traditionally pastoralists, and have a mean herd size of 59 cattle $(n=63)$, while the Tswana speakers, predominantly mixed farmers, have on average 22 cattle $(n=63)$. With regard to crop land, similar cultural factors also come into play. As pastoralists, the Herero either do not engage in crop production, or tend to do so only on a limited basis. Although the overall mean field size in Habu is 3.5 ha, for Tswana households it is 4.3 ha, and for Herero households only 2.5 ha. The importance of most of the household assets lies less in their financial value and more in their use as tools that contribute to livelihood strategies or health. Again, distribution is strongly skewed, with $10 \%$ of households owning $40 \%$ of the cumulative assets in the community.

Natural capital is particularly important in communities as remote as Habu. Without electricity, most people cook on fires, with $95.9 \%$ of households regularly collecting firewood. $81 \%$ of households collect wild food plants, and $12.4 \%$ report hunting small game and birds. Most households regularly collect five of eight different types of natural resources identified in the community. These are: thatching grass for 
roofing, reeds for walls, palm leaves for baskets, tree stems for poles, firewood, medicinal plants, food plants, fish, and small game and birds. About $28 \%$ of households get some money from selling natural resources.

In terms of human capital, the number of adults in the household represents labor availability. The average household comprises four adults at 18 years and over, and four children. The mean dependency ratio, that is, the number of children divided by number of adults, is 1.21 ; however, the dependency ratio for female-headed households at 1.51 is significantly higher $(F=3.991, p=0.021)$ than it is for maleheaded households, at 0.97 . Formal education is a relatively recent phenomenon in Habu village. In 1977, a group of community members began a self-help primary school under a tree, with the first classroom built in 1980 . Hence there is a strong negative correlation between the age of household head and highest level of education attained by the head (Kendall's tau-b $=-0.611, p<0.000)$. The mean level of education for household heads is some years of primary schooling. However, younger members of households usually have some secondary schooling, so even "older" households have access to people with formal education. For Habu, the mean for the highest education in the household is completion of junior secondary school, that is, nine years of school.

Social capital interacts strongly with access to other forms of capital. Habu comprises people of a mix of ethnic origins, although $52.4 \%$ identify themselves as Batswana, speaking Tswana at home - this includes households of Yei origin now assimilated into Tswana culture. A further $44.1 \%$ are Herero, with only a couple of purely Yei or Hambukushu households. There is a significant correlation (Pearson Chi-square 85.504, $p<0.000$ ) between ethnicity and general household location: $93 \%$ of Tswana households are found within the village core, whereas $76.6 \%$ of Herero households are located outside at cattle posts. This correlation is associated with the Herero focus on livestock as a main livelihood activity. Just over half (52.4\%) of households in Habu are male-headed with the head present, $6.9 \%$ are male-headed with the head absent for more than six months of the year, and $40.7 \%$ are female-headed, whether single or widowed. Members of female-headed households were as likely to attend "kgotla," or formal village meetings as those of male-headed households. However, Herero households attend such meetings significantly less frequently than Tswana households $(F=2.899, p=0.091)$. Although this might be explained to some degree by the fact that more Herero families live outside the village core, location, that is, whether in or out of the village, did not correlate with a significant difference in frequency of attending "kgotla," meetings $(F=1.838, p=0.163)$, reinforcing the commonly held view that Herero people are politically marginalized. Habu, as with most rural Botswana communities, has several community organizations (e.g., village development committee, village health committee, parent-teacher association, farmers' committee). 64\% of households are involved in at least one of the eight organizations identified in the community. However, only $10 \%$ are involved in three or more such organizations. Churches play an important role in people's social lives. Some $85.5 \%$ of households have at least one member attending church, although 11 different church groups were identified.

\section{Variation in Resilience According to Key Socioeconomic Characteristics}

The distributions of the three different indices of household resilience differ in structure (Fig. 6), reflecting the different characteristics of resilience that they represent. The Livelihood Diversity Index suggests that most households typically pursue multiple strategies (Fig. 6a). Although there are no significant differences between ethnic groups or households headed by men or women, households with older heads have higher livelihood diversity. This may simply be because houses with older heads tend to be multigenerational and, therefore, larger with greater labor availability (Table 1). Most commonly, households will engage in crop production, cattle rearing, smallstock rearing, collection of natural resources, and one or two small businesses.

Fig. 6. Distribution of the different indices of resilience across Habu households, showing a) Livelihood Diversity, b) Wealth Index, and c) Resilience Index.

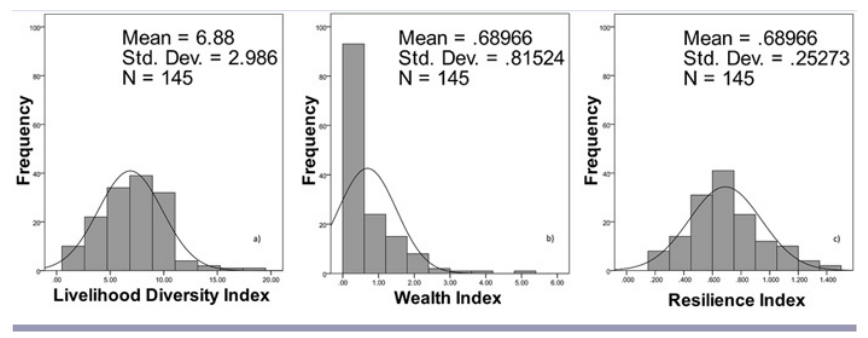

Wealth is extremely skewed (Fig. 6b), and the community has a GINI coefficient of 0.72 . Wealth is strongly associated with three key social characteristics: gender of household head, ethnicity, and highest education in the household (Table 1), as well as with age of head and household size. With the exception of age of household head, these characteristics are all incorporated in the Resilience Index and, therefore, associations with them were not analyzed.

\section{Habu Household Exchange Networks}

Our initial analysis demonstrated that almost all households exchange information with the veterinary officer, the crop officer, and the local nurse. Because we are more interested in the informal exchanges between households, as opposed to those with institutionalized positions, we removed these three nodes from all further analysis. As expected, a number of households living outside of Habu form part of the exchange 
Table 1. Measures of association between key sociocultural characteristics and the Livelihood Diversity Index and Wealth Index.

\begin{tabular}{|c|c|c|c|c|c|}
\hline & $\begin{array}{l}\text { Gender of household } \\
\text { head }\end{array}$ & Ethnicity & $\begin{array}{c}\text { Highest education in } \\
\text { household }\end{array}$ & Age of household head & Household size \\
\hline $\begin{array}{l}\text { Gender of household } \\
\text { head }\end{array}$ & -- & $\begin{array}{l}P=7.501 \\
p=0.024\end{array}$ & $\begin{aligned}{ }^{\ddagger} F & =0.000 \\
p & =0.991\end{aligned}$ & $\begin{aligned} F & =0.051 \\
p & =0.822\end{aligned}$ & $\begin{aligned} F & =0.366 \\
p & =0.546\end{aligned}$ \\
\hline Ethnicity & -- & -- & $\begin{aligned} F & =0.629 \\
p & =0.429\end{aligned}$ & $\begin{aligned} F & =0.079 \\
p & =0.779\end{aligned}$ & $\begin{array}{c}\boldsymbol{F}=6.724 \\
\boldsymbol{p}=0.011 \\
\mathrm{df}=1 ; 138\end{array}$ \\
\hline $\begin{array}{l}\text { Highest education in } \\
\text { household }\end{array}$ & -- & -- & -- & $\begin{aligned}{ }^{\S} K & =-0.042 \\
p & =0.511\end{aligned}$ & $\begin{aligned} \boldsymbol{K} & =0.255 \\
\boldsymbol{p} & <0.000\end{aligned}$ \\
\hline Age of household head & -- & -- & -- & -- & $\begin{array}{l}K=0.285 \\
p<0.000\end{array}$ \\
\hline Livelihood Diversity & $\begin{aligned} F & =0.634 \\
p & =0.427\end{aligned}$ & $\begin{aligned} F & =1.945 \\
p & =0.165\end{aligned}$ & $\begin{aligned} K & =0.036 \\
p & =0.581\end{aligned}$ & $\begin{aligned} \boldsymbol{K} & =0.122 \\
\boldsymbol{p} & =0.038\end{aligned}$ & $\begin{aligned} K & =0.283 \\
\boldsymbol{p} & <0.000\end{aligned}$ \\
\hline Wealth Index & $\begin{array}{c}\boldsymbol{F}=12.048 \\
\boldsymbol{p}=0.001 \\
\mathrm{df}=1 ; 142\end{array}$ & $\begin{array}{c}\boldsymbol{F}=25.751 \\
\boldsymbol{p}<0.000 \\
\mathrm{df}=12 ; 138\end{array}$ & $\begin{array}{l}\boldsymbol{K}=0.218 \\
\boldsymbol{p}<0.000\end{array}$ & $\begin{array}{l}\boldsymbol{K}=0.201 \\
\boldsymbol{p}<0.000\end{array}$ & $\begin{array}{l}\boldsymbol{K}=0.347 \\
\boldsymbol{p}<0.000\end{array}$ \\
\hline Resilience Index & -- & -- & -- & $\begin{aligned} \boldsymbol{K} & =0.144 \\
\boldsymbol{p} & =0.011\end{aligned}$ & -- \\
\hline
\end{tabular}

Notes: Tests were not run for the Resilience Index against those characteristics that contribute to it. Relationships significant at below the 0.1 level are bold.

${ }^{\dagger} P=$ Pearson Chi-square test value

${ }^{\ddagger} F=$ ANOVA test value, with first df value being numerator and second being denominator

${ }^{\S} K=$ Kendall's tau-b test value

networks of Habu residents. These external households are numbered 1146 and higher in our analysis of the information, labor, food, and money-exchange networks.

Fig. 7 shows the more central households, that is, with betweenness $>300$, in the exchange of information in times of shock. The households that are colored are those that house either the chief (1006), the traditional healer (1128) or someone who holds a leadership position in a community organization, such as in the village development committee. Beyond the two households with the highest betweenness values, both housing two key community leaders, leadership does not appear to play a significant role in providing network connectivity.

The labor network (Fig. 8) is the most dense of all four exchange networks, followed by food, money, and information networks. We expected that larger households, meaning those with more adults, would have a more active labor network and, therefore, be more central to labor exchange in the community. This is clearly not the case. We divided the number of adults per household into four groups (1-2, 3-6, 7-9, 10 or more) and ranked them accordingly, depicted in gray-scale, with black nodes being the households with 10 or more adults. Household 1047 is the only household with 10 or more adults that is relatively well connected. Households with 1-2 adults (light gray) play an unexpectedly central role in the exchange of labor. This may in part be a reflection of the 2-way nature of the exchange; these may be households that are frequently exchanging labor inwards. This network also involves households from outside the community (shown in white), but none of these are highly central to the network.

Fig. 9 illustrates that male-headed households (circles) are more central to the money-exchange network than femaleheaded ones (triangles), and also how wealth (blue) is dominated by these male-headed households. De facto femaleheaded households are those where a man's name is given as the household head, but in fact a woman acts as the head as the man is absent most of the time. De jure female-headed households are those where the woman is legally the head. Clearly, gender plays a key role in both wealth and the exchange of money.

The money-exchange network is less dense (0.022) than the labor and food networks, but still significantly more dense than the information-exchange network. Eight households 
Fig. 7. Information exchange network showing more centralized households (indicated by size of square) and community leaders (colored nodes).

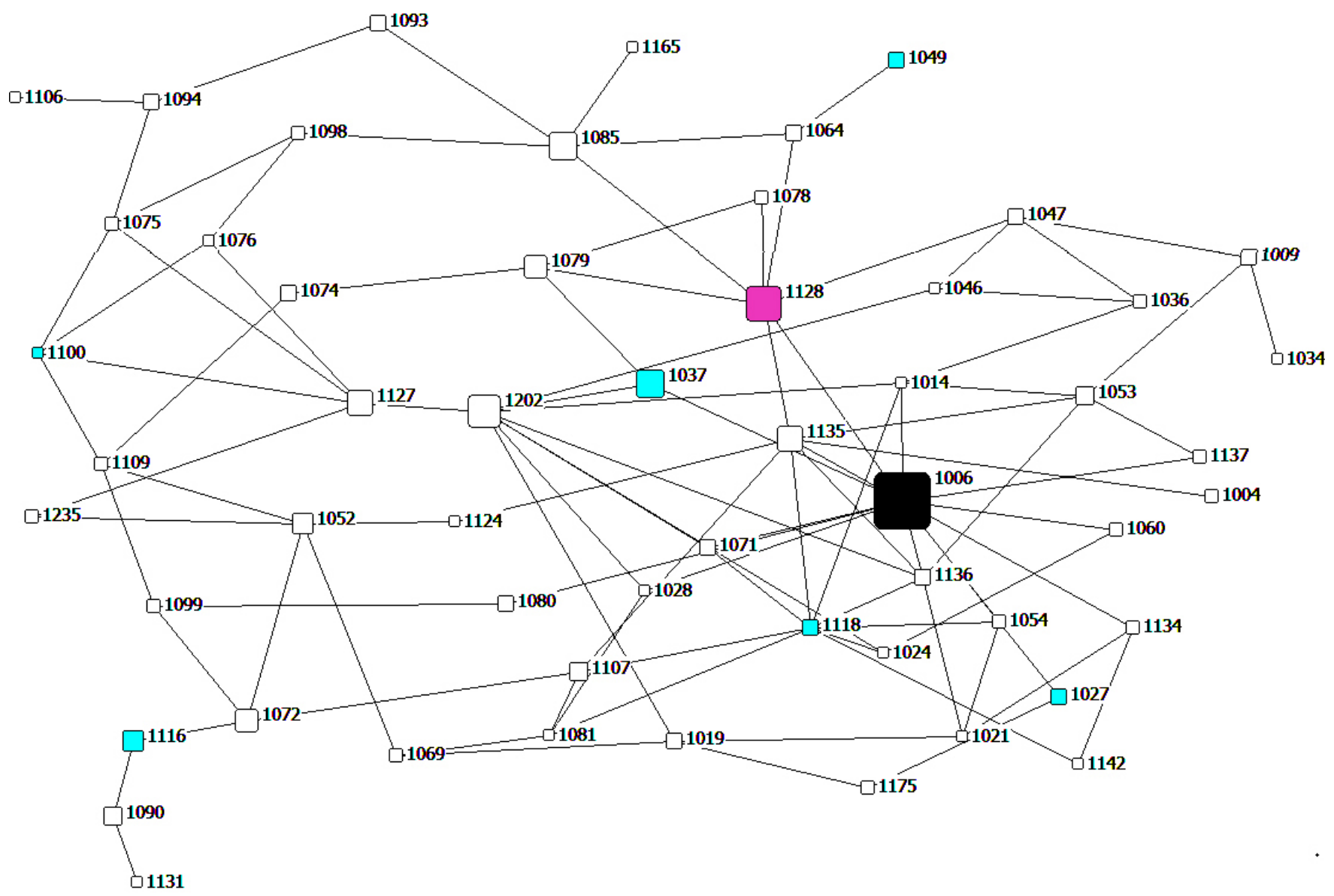

have degree centrality values of 10 or higher which is on a par with all except the labor-exchange network which had twice as many key players. Interestingly, household 1021 ranked first in degree centrality for both money and food-exchange networks. This is a multigenerational household with seven adults and five children. The household head is an 83-yr old male who speaks Setswana, but who does not currently serve in a leadership position in the community. None of the most centralized households resides outside of the community, suggesting that external sources of money do not serve as primary sources of loans.

\section{Relationship Between Social Network Centrality and Sociocultural Characteristics}

We investigated the relationship between the key sociocultural characteristics presented earlier and the centrality measures obtained from the social network analysis using analysis of variance (ANOVA) and Kendall's tau-b. The results are summarized in Table 2.
The gender of the household head is highly correlated with both degree and betweenness centrality measures, with female-headed households scoring much lower than their male counterparts. As expected, the age of the household head and household size was also positively correlated with network centrality since both of these are likely to lead to more connections through simply being larger. Surprisingly, except in two cases, ethnicity and education did not prove to be highly correlated with network centrality. This can be partially explained by the fact that older community members have less education, but because of their seniority are more likely to head their household.

\section{Connectivity and Resilience in Habu}

Throughout, the measures of network connectivity are strongly correlated to the three different indicators of resilience Notably, the headman of the village has both high connectivity and high resilience. However, other community members who are highly connected, such as the ward headmen 
Fig. 8. Labor Exchange Network where larger nodes have higher betweenness values and grayscale reflects number of adults in household (darker nodes have more).

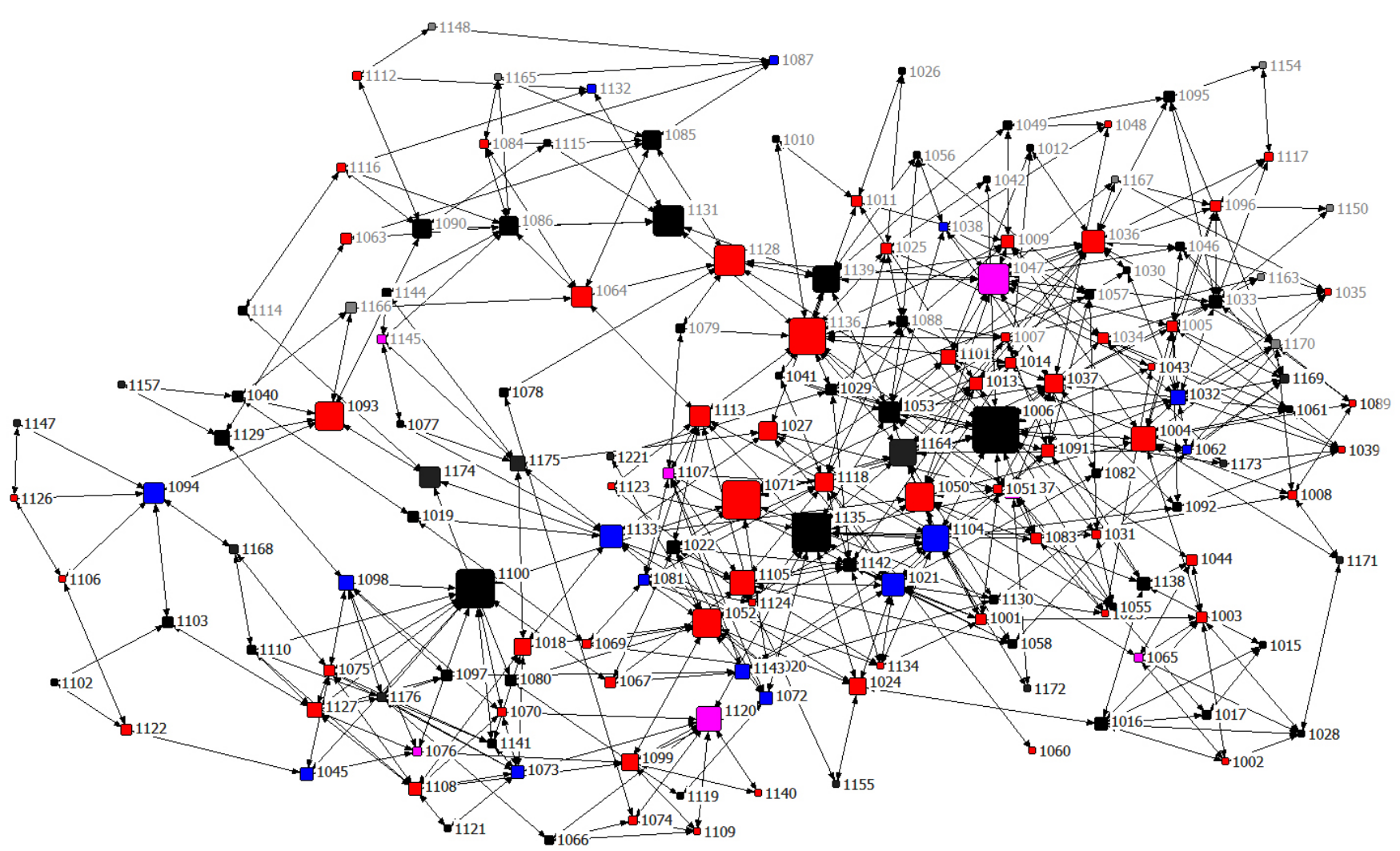

Note: All isolates and pendants (no more than one connection) have been removed.

and village development committee members, are not necessarily among the top 20 resilient households. Two examples of highly connected households are presented in Text Box 1, and two of households with limited connectivity are presented in Text Box 2.

\section{Box 1. Strongly connected households}

Households 1037 and 1128 have some of the highest overall network values across all four exchange sectors. Here, we profile their socioeconomic characteristics.

Household 1037 comprises an extended family from the dominant Setswana-speaking ethnic group, living in the village core. It is maleheaded, and the 63-yr old head is one of five ward headmen in the village. The household is medium-sized, with four adults and three children. The highest education in the household is a post-high school technical college qualification. With only four adults in the household, it is important to note that three of them hold jobs. This is perhaps why the household is not engaged in any small businesses. The homestead's buildings are primarily built of mud bricks, with corrugated iron roofs. There is a private water connection to the household. The household owns a donkey cart, a water pump, a TV, DVD player, radio, and cellphone. It has a range of agricultural tools, as well as both a shotgun and a rifle. They have 3 ha of crop land, of which they planted two in 2010 , harvesting $150 \mathrm{~kg}$ of maize. Household members own 104 head of cattle, 40 goats, 15 sheep, 15 donkeys, and six horses. They regularly collect eight different types of natural resources. Household members attend village kgotla meetings on average 5 times a month, and are involved in three different community institutions. Based on the different forms of livelihood capitals, the household ranks $14^{\text {th }}$ in the community in terms of the Wealth Index and $9^{\text {th }}$ in terms of the Resilience Index.

Household 1128 is from the Thimbukushu ethnic group and is headed by a traditional healer. There are 6 adults and one child in this 3generational household. Although the two oldest members have no formal education, two of the younger adults have completed senior high school, and a third has completed junior high school. No-one in the household has formal employment, but the household is engaged in four different small businesses, notably brick laying and the sale of collected natural resources. They own a donkey cart, a water pump, a satellite TV, a DVD player and a radio, a stove, a cell-phone, agricultural tools, and both a shotgun and a rifle. Buildings in the homestead are built primarily with cinderblocks and roofed with 
Fig. 9. Money exchange network showing betweenness centrality ${ }^{\dagger}$, Wealth Index $x^{\ddagger}$, and gender of household head ${ }^{\S}$.

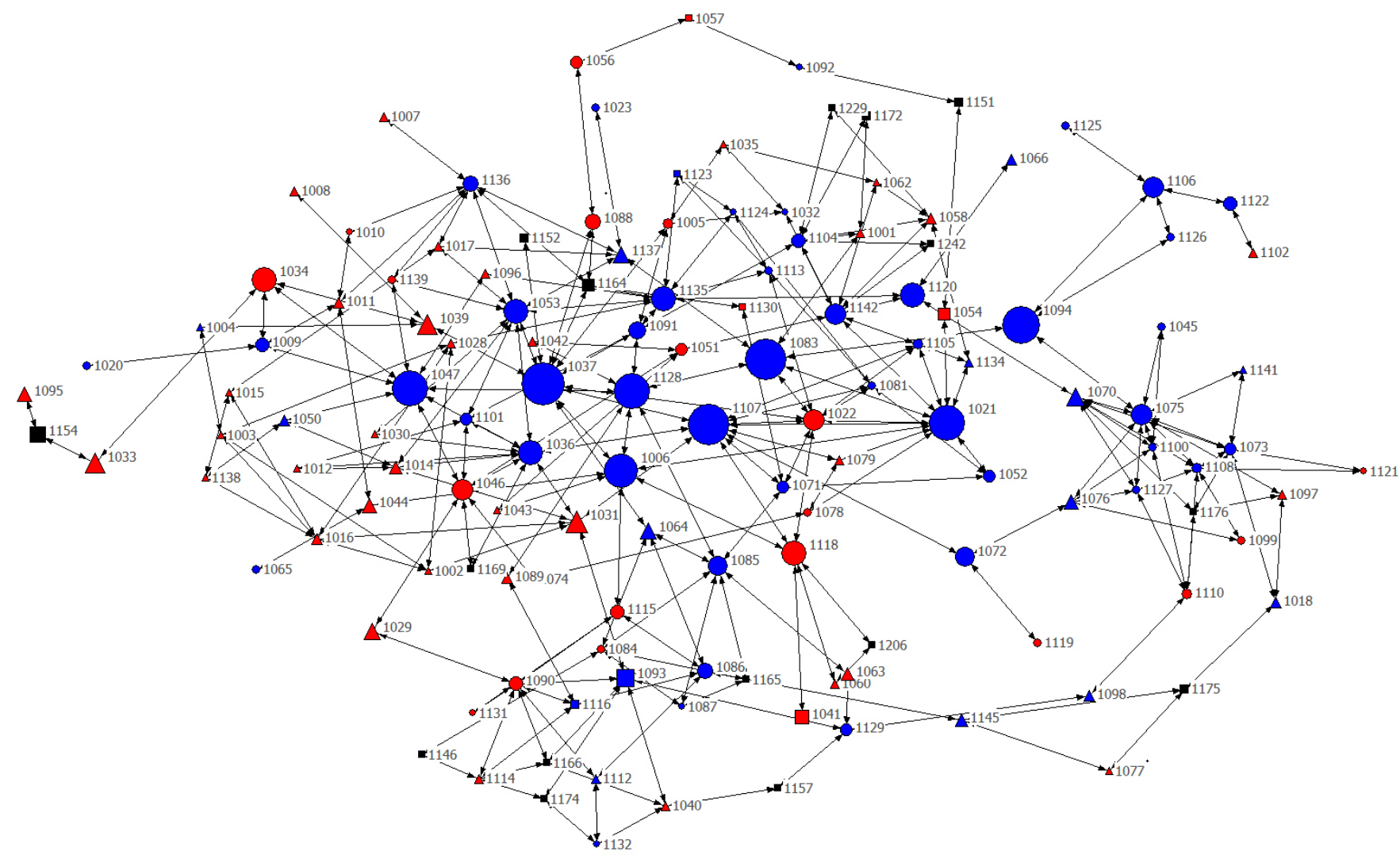

${ }^{\dagger}$ Size of node.

"Top half is blue, lower half is red.

${ }^{\S}$ Circles are male-headed, squares are de facto female-headed, and triangles are de jure female-headed.

corrugated iron. The household has a private water connection. They have 6 ha of cropland, and regularly sell surplus as a source of income. Together, members of the household own 80 head of cattle, about 200 goats and 45 sheep, and sell meat and milk. They also have 23 donkeys. They collect five different types of natural resources. Household members attend "kgotla" meetings only infrequently, but one person is a member of the village health committee, and another is a member of the farmers' committee. The household ranks $20^{\text {th }}$ in terms of the Wealth Index, and $19^{\text {th }}$ in terms of the Resilience Index.

Information is the least tangible of exchanges and, although it is significantly correlated with the measures of resilience, it is not as strongly correlated as the other exchange networks. When considering the ways in which household level information exchanges relate to other information-related forms of social capital, there are again significant relationships, suggesting that the social network figures do indeed capture how connected households are within their community (Table 3). The fact that other types of exchanges, as indicated by the average values for all exchange types, are correlated with attendance at "kgotla" meetings, but not information exchanges, is difficult to understand. However, it could be because most people, even those who do not share advice and information at the household level, use the "kgotla" as a formal source of information. Our data shows that a few households did not attend any "kgotla" meetings, but the most active household went to 150 of these meetings per year and on average households attended "kgotla" meetings 30 times per year.

Connectivity and other forms of social capital that contribute to resilience are generally enhanced through attending community "kgotla" meetings, church, and actively participating in other organizations such as the village 
Table 2. Measures of association between key sociocultural characteristics and the social network metrics of degree centrality (DC) and betweenness (B) for different exchange types.

\begin{tabular}{|c|c|c|c|c|c|}
\hline & $\begin{array}{l}\text { Gender of household } \\
\text { head }\end{array}$ & Ethnicity & $\begin{array}{l}\text { Highest education in } \\
\text { household }\end{array}$ & Age of household head & Household size \\
\hline DC-Information & $\begin{array}{l}\boldsymbol{F}=10.178 \\
\boldsymbol{p}=0.002 \\
\mathrm{df}=1 ; 132\end{array}$ & $\begin{array}{l}F=0.958 \\
p=0.329\end{array}$ & $\begin{array}{l}{ }^{\ddagger} K=0.107 \\
p=0.104\end{array}$ & $\begin{array}{l}K=0.052 \\
p=0.382\end{array}$ & $\begin{array}{l}K=0.087 \\
p=0.152\end{array}$ \\
\hline DC-Labor & $\begin{array}{l}\boldsymbol{F}=12.446 \\
\boldsymbol{p}=0.001 \\
\mathrm{df}=1 ; 132\end{array}$ & $\begin{array}{l}F=0.430 \\
p=0.513\end{array}$ & $\begin{array}{l}K=0.092 \\
p=0.155\end{array}$ & $\begin{array}{l}\boldsymbol{K}=0.114 \\
\boldsymbol{p}=0.054\end{array}$ & $\begin{array}{l}\boldsymbol{K}=0.242 \\
\boldsymbol{p}<0.000\end{array}$ \\
\hline DC-Food & $\begin{array}{l}\boldsymbol{F}=8.816 \\
\boldsymbol{p}=0.004 \\
\mathrm{df}=1 ; 132\end{array}$ & $\begin{array}{l}F=0.087 \\
p=0.769\end{array}$ & $\begin{array}{l}K=0.052 \\
p=0.420\end{array}$ & $\begin{array}{l}\boldsymbol{K}=0.119 \\
\boldsymbol{p}=0.043\end{array}$ & $\begin{array}{l}\boldsymbol{K}=0.243 \\
\boldsymbol{p}<0.000\end{array}$ \\
\hline DC-Money & $\begin{array}{l}\boldsymbol{F}=13.601 \\
\boldsymbol{p}<0.000 \\
\mathrm{df}=1 ; 132\end{array}$ & $\begin{array}{l}F=0.188 \\
p=0.665\end{array}$ & $\begin{array}{l}K=0.055 \\
p=0.395\end{array}$ & $\begin{array}{l}K=0.060 \\
p=0.308\end{array}$ & $\begin{array}{l}\boldsymbol{K}=0.179 \\
\boldsymbol{p}=0.003\end{array}$ \\
\hline DC-Overall & $\begin{array}{l}\boldsymbol{F}=14.689 \\
\boldsymbol{p}<0.000 \\
\mathrm{df}=1 ; 132\end{array}$ & $\begin{array}{l}F=0.174 \\
p=0.677\end{array}$ & $\begin{array}{l}K=0.081 \\
p=0.203\end{array}$ & $\begin{array}{l}\boldsymbol{K}=0.101 \\
\boldsymbol{p}=0.079\end{array}$ & $\begin{array}{l}\boldsymbol{K}=0.224 \\
\boldsymbol{p}<0.000\end{array}$ \\
\hline B-Information & $\begin{array}{l}\boldsymbol{F}=7.539 \\
\boldsymbol{p}=0.007 \\
\mathrm{df}=1 ; 132\end{array}$ & $\begin{array}{l}F=0.705 \\
p=0.403\end{array}$ & $\begin{array}{l}K=0.087 \\
p=0.193\end{array}$ & $\begin{array}{l}K=0.097 \\
p=0.107\end{array}$ & $\begin{array}{l}\boldsymbol{K}=0.189 \\
\boldsymbol{p}=0.002\end{array}$ \\
\hline B-Labor & $\begin{array}{l}\boldsymbol{F}=12.223 \\
\boldsymbol{p}=0.001 \\
\mathrm{df}=1 ; 132\end{array}$ & $\begin{array}{l}F=0.156 \\
p=0.694\end{array}$ & $\begin{array}{l}\boldsymbol{K}=0.128 \\
\boldsymbol{p}=0.042\end{array}$ & $\begin{array}{l}\boldsymbol{K}=0.117 \\
\boldsymbol{p}=0.042\end{array}$ & $\begin{array}{l}\boldsymbol{K}=0.201 \\
\boldsymbol{p}=0.001\end{array}$ \\
\hline B-Food & $\begin{array}{l}\boldsymbol{F}=4.866 \\
\boldsymbol{p}=0.029 \\
\mathrm{df}=1 ; 132\end{array}$ & $\begin{array}{l}F=0.267 \\
p=0.607\end{array}$ & $\begin{array}{l}K=0.050 \\
p=0.433\end{array}$ & $\begin{array}{l}\boldsymbol{K}=0.176 \\
\boldsymbol{p}=0.002\end{array}$ & $\begin{array}{l}\boldsymbol{K}=0.177 \\
\boldsymbol{p}=0.002\end{array}$ \\
\hline B-Money & $\begin{array}{l}\boldsymbol{F}=14.181 \\
\boldsymbol{p}<0.000 \\
\mathrm{df}=1 ; 132\end{array}$ & $\begin{array}{l}F=0.281 \\
p=0.597\end{array}$ & $\begin{array}{l}K=0.066 \\
p=0.303\end{array}$ & $\begin{array}{c}\boldsymbol{K}=0.130 \\
\boldsymbol{p}=0.026\end{array}$ & $\begin{array}{l}\boldsymbol{K}=0.103 \\
\boldsymbol{p}=0.082\end{array}$ \\
\hline B-Overall & $\begin{array}{l}\boldsymbol{F}=15.003 \\
\boldsymbol{p}<0.000 \\
\mathrm{df}=1 ; 132\end{array}$ & $\begin{array}{l}F=0.252 \\
p=0.616\end{array}$ & $\begin{array}{l}\boldsymbol{K}=0.108 \\
\boldsymbol{p}=0.085\end{array}$ & $\begin{array}{l}\boldsymbol{K}=0.182 \\
\boldsymbol{p}=0.001\end{array}$ & $\begin{array}{l}\boldsymbol{K}=0.200 \\
\boldsymbol{p}=0.001\end{array}$ \\
\hline
\end{tabular}

Relationships significant at below the 0.1 level are bold.

${ }^{\dagger} F=$ ANOVA test value, with first df value being numerator and second being denominator

${ }^{*} K=$ Kendall's tau-b test value

development committee. In Table 3, we show the statistical relationship between connectivity, as measured by degree centrality and betweenness, and other indicators of connectivity, reflecting the extent to which a household participates in community activities. Since we see these activities primarily as fora for exchanging information, we first analyze information networks and then examine average centrality measures across all four networks (information, labor, food, and money).

\section{Overall Exchanges: Degree Centrality and Indicators of Resilience}

These results show how degree centrality for the four different exchange networks; that is, information, labor, food and money, and an overall average for these four networks, correlates to the three different measures of resilience. Generally, the associations seem to be strongest for labor exchange degree centrality (Table 4), suggesting again that household size and labor availability might determine both the number of connections and the amount of capital that households can accumulate and hence their adaptive capacity. Livelihood diversity is most strongly correlated with degree centrality for food exchanges, perhaps because of the subsistence nature of household livelihoods.

\section{Box 2. Weakly connected households}

Households 1140 and 1121's degree centrality and betweenness values are consistently among the lowest in the networks. Their characteristics are given here.

Household 1140 is situated at one of the cattle posts outside the village core. The household is from the politically minority Herero ethnic group. It is headed by a 61-yr old widow, and comprises 4 adults and 7 children. One household member has completed senior high school. No-one has formal employment; nor does the household earn money from any small business activities. The household has a donkey cart, 
Table 3. Nonparametric correlations between information and average degree centrality and betweenness as indicators of connectivity, and other measures of information-related social capital.

\begin{tabular}{llll}
\hline \hline & $\begin{array}{l}\text { Degree centrality: } \\
\text { information }\end{array}$ & Betweenness: information & $\begin{array}{l}\text { Degree centrality: average } \\
\text { for all four networks }\end{array}$ \\
\hline $\begin{array}{l}\text { Attendance at kgotla } \\
\text { Attendance at church }\end{array}$ & $\boldsymbol{K}=0.005, p=0.929$ & $K=0.040, p=0.524$ & $\boldsymbol{K}=0.132, \boldsymbol{p}=0.026$ \\
fumber of institutions & $\boldsymbol{K}=0.184, \boldsymbol{p}=0.005$ & $\boldsymbol{K}=0.144, \boldsymbol{p}=0.047$ & $\boldsymbol{K}=0.213, \boldsymbol{p}=0.002$ \\
$\begin{array}{l}\text { Nousehold members involved } \\
\text { in }\end{array}$ & $\boldsymbol{K}=0.135, \boldsymbol{p}=0.041$ & $\boldsymbol{K}=0.174, \boldsymbol{p}=0.006 \quad \boldsymbol{K}=0.153, \boldsymbol{p}=0.026 \quad 0.202, \boldsymbol{p}=0.002 \quad$ \\
\hline
\end{tabular}

Note: Relationships significant at below the 0.1 level are bold. ${ }^{\dagger} K=$ Kendall's tau_b

and both a generator and a water pump. They also own a cell phone, a sewing machine, and some agricultural tools. The buildings are made of mud bricks and roofed with corrugated iron. Domestic water is pumped from a borehole. The family does not grow crops and, therefore, has no fields. The household owns 60 head of cattle, 30 goats, three donkeys and one horse. They regularly collect three different natural resource types. Someone from the household attends "kgotla" meetings about once a month, and household members are members of four community institutions. The household is reasonably well off, ranking $33^{\text {rd }}$ in the community in terms of wealth, but appears to have low social and human capital, ranking only $112^{\text {th }}$ in terms of the Resilience Index.

Household 1121 is also a Herero family located at a cattlepost outside the main village. It is male-headed, and young, with three children aged five and under. The wife has the highest level of educationshe completed junior secondary school. Neither of the couple has a job, although they do engage in smithing, thatching and the sale of livestock products from time to time. They have no means of transport, other than horses and donkeys, and own no mechanical equipment beyond a cell phone and a sewing machine. They have only basic agricultural tools for hoeing. The house is made of mud brick walls with a thatch roof. The family draws water from the river. They have a small field for crops, but did not plant in 2010. They own 15 cows, 10 goats, and 17 sheep, as well as eight donkeys and four horses. They regularly harvest five different types of natural resources. They attend "kgotla" meetings about three times a month, but are not active in any other community organizations. The household ranks $82^{\text {nd }}$ in terms of wealth, and $100^{\text {th }}$ in terms of the Resilience Index.

\section{Overall Exchanges: Betweenness and Indicators of Resilience}

As with overall degree centrality, overall betweenness is reported here as exchanges in terms of the four different exchange networks: information, labor, food, and money, and as an average of the four networks. Representing more of a "bridging" capacity, betweenness could be interpreted as an indication of how broadly a household spreads its exchanges, implying also greater structural complexity to the relationships than merely the direct connections of each household.
Therefore, we expect higher values in the relationships of betweenness-as compared to degree centrality-with the different measures of resilience. For the most part, a comparison of the values in Table 4 and Table 5 confirm this to be the case. Again, "livelihood diversity" is most strongly associated with food exchanges. Yet, whereas the Wealth Index is still correlated with labor exchanges, the Resilience Index has the strongest relationship with the average of all four types of network exchanges (Table 5).

Betweenness may be a better indicator of network centrality because it takes into account both direct and indirect connections to a household. Households with high betweenness values are important conduits for many other households that are not directly connected to them and, therefore, betweenness may be a better measure of overall connectivity within the community than degree centrality. At the household level, overall betweenness (all exchange types combined) has a slightly higher association with the wealth and resilience indices than does overall degree centrality (Table 4 and Table 5). Whereas high degree centrality supports household resilience by ensuring multiple options (diversity) for exchanges, high betweenness enhances the range of spheres to which a household can extend its exchanges (structural complexity). Both aspects appear to be important.

\section{CONCLUSION}

From the outside, the community of Habu generally appears fairly poor, and highly dependent on the natural resources base, both through subsistence agriculture and through direct offtake of wild plants and animals. Natural resources, that is, in the form of firewood, also provide the main source of energy within households, providing a further indication of this dependency and the integrated social-ecological system that is Habu. However, there is considerable variation in natural capital, and thus in the ways that people interact with the environment around them. Indeed, this variation can be seen in the distribution of all forms of capital. Importantly, the levels of the different forms of capital co-vary, so that households with greater social and human capital tend also to have greater physical and financial capital, for example. The overall picture of total capital for the different households 
Table 4. Nonparametric correlations between degree centrality as an indicator of connectivity and the three different indicators of resilience.

\begin{tabular}{|c|c|c|c|c|c|}
\hline & \multicolumn{5}{|c|}{ Degree centrality: } \\
\hline & information & labor & food & money & overall \\
\hline Livelihood Diversity & $\begin{array}{l}{ }^{\dagger} K=0.128 \\
p=0.035\end{array}$ & $\begin{array}{l}K=0.267 \\
p<0.000\end{array}$ & $\begin{array}{l}K=0.284 \\
p<0.000\end{array}$ & $\begin{array}{l}K=0.198 \\
p=0.001\end{array}$ & $\begin{array}{l}K=0.251 \\
p<0.000\end{array}$ \\
\hline Wealth Index & $\begin{array}{l}K=0.198 \\
p=0.001\end{array}$ & $\begin{array}{l}K=0.292 \\
p<0.000\end{array}$ & $\begin{array}{l}K=0.271 \\
p<0.000\end{array}$ & $\begin{array}{l}K=0.253 \\
p<0.000\end{array}$ & $\begin{array}{l}K=0.289 \\
p<0.000\end{array}$ \\
\hline Resilience Index & $\begin{array}{l}K=0.208 \\
p<0.000\end{array}$ & $\begin{array}{l}K=0.376 \\
p<0.000\end{array}$ & $\begin{array}{l}K=0.355 \\
p<0.000\end{array}$ & $\begin{array}{l}K=0.275 \\
p<0.000\end{array}$ & $\begin{array}{l}K=0.348 \\
p<0.000\end{array}$ \\
\hline
\end{tabular}

Notes: All relationships are significant at below the 0.05 level. The highest relationship for each indicator of resilience is italicized.

${ }^{\dagger} K=$ Kendall's tau_b

presents a picture of variation in the adaptive capacity, or resilience, of the community's households (Vincent 2007) that is implicit in the findings for communities in other parts of southern Africa (Twyman 2001, Cassidy 2003, Shackleton and Shackleton 2006, Kgathi et al. 2007, Sallu et al. 2009, Sallu et al. 2010, Kgathi and Motsholapheko 2011). In turn, this variation is associated with a variation in connectivity. Households with greater resilience are more connected (Adger 2003). Material forms of capital, for example, the physical and financial capitals which comprise the Wealth Index, are strongly associated with position in the social network. Clearly, as suggested by the stronger associations with the Resilience Index, the less tangible socioeconomic characteristics captured by human, social, and natural capital enhance this relationship. This is further shown in the strong associations that position in social networks has with other forms of social capital.

The analysis at the household level is useful: key families, whose members play important roles in the community, are captured as having both high network centrality and high resilience (Lhotka et al. 2008). Because the household is the unit of consumption and production, it stands to reason that individuals who are part of the household occupying a central role such as that of ward headman, will benefit from the connections he or she may individually bring to the household. This is not to suggest that all members of the household are equally resilient. For example, gender may influence the ability to engage in certain livelihood strategies. In Habu at least, the gender of the household head is critical, affecting the resilience of not just the individual, but the entire household.

Our social network data show that, aside from the central role played by the chief and the traditional healer, the current leadership is not key to information exchange. The laborexchange network is the most active network with a broader group of key players than any of the other networks. Our expectation that households with more adults would be more central to the network did not prove to be valid. The moneyexchange network showed that male-headed households were not only most central to the network, but they also held more wealth, as measured by the Wealth Index. Although we have not shown any figures representing the food-exchange network, female-headed households were much more central there than in the money-exchange network, but with a few exceptions, wealthier households were even more central. This is also surprising, as we expected poorer households to be much more active in the food-exchange network. Finally, the food-exchange network did not have any isolates, which means that all households played some role in this network.

Degree centrality and betweenness provide different types of linkages within the community system, but each is strongly associated with household resilience. It is likely that both aspects would enhance household resilience, through their different functions of providing redundancy and expanding the interactions into different subsets of the community. What is important is that households with low resilience because of limited capital are further vulnerable because they have weak connectivity to other households with whom they could exchange goods and services in times of shock (Busby et al. 2010). Such marginal households should be targeted for additional support in times of stress such as drought, outbreaks of livestock disease, or human health issues such as malaria and HIV/AIDS. By focusing on weakly connected households, such as isolates, development agencies could better ensure the survivability of all the community's constituents (Food, Agriculture and Natural Resources Policy Analysis Network 2006). By the same token, households with high betweenness scores, particularly in terms of information exchanges, could be used as conduits for disseminating disaster awareness and other information relating to external stressors that a community may be facing.

Does the connectivity of these exchanges confer added resilience, or does greater resilience allow households to be more connected? Determining that strong relationships do indeed exist between these two characteristics in rural SESs is an important first step. This knowledge helps us understand the nature of the relationship between the redundancy implicit in high levels of degree centrality and betweenness, and the 
Table 5. Nonparametric correlations between "betweenness" as an indicator of connectivity and the three different indicators of resilience.

\begin{tabular}{|c|c|c|c|c|c|}
\hline & \multicolumn{5}{|c|}{ Betweennes: } \\
\hline & information & labor & food & money & overall \\
\hline Livelihood Diversity & $\begin{array}{l}{ }^{\dagger} K=0.130 \\
p=0.034\end{array}$ & $\begin{array}{l}K=0.202 \\
p=0.001\end{array}$ & $\begin{array}{l}K=0.260 \\
p<0.000\end{array}$ & $\begin{array}{l}K=0.213 \\
p<0.000\end{array}$ & $\begin{array}{l}K=0.251 \\
p<0.000\end{array}$ \\
\hline Wealth Index & $\begin{array}{l}K=0.270 \\
p<0.000\end{array}$ & $\begin{array}{l}K=0.309 \\
p<0.000\end{array}$ & $\begin{array}{l}K=0.254 \\
p<0.000\end{array}$ & $\begin{array}{l}K=0.231 \\
p<0.000\end{array}$ & $\begin{array}{l}K=0.321 \\
p<0.000\end{array}$ \\
\hline Resilience Index & $\begin{array}{l}K=0.234 \\
p<0.000\end{array}$ & $\begin{array}{l}K=0.351 \\
p<0.000\end{array}$ & $\begin{array}{l}K=0.344 \\
p<0.000\end{array}$ & $\begin{array}{l}K=0.280 \\
p<0.000\end{array}$ & $\begin{array}{l}K=0.364 \\
p<0.000\end{array}$ \\
\hline
\end{tabular}

Notes: All relationships are significant at below the 0.05 level. The highest relationship for each indicator of resilience is italicized.

${ }^{\dagger} K=$ Kendall's tau_b

amounts and range of capital that contribute to household resilience. Exploring social networks as a measure of system connectivity has allowed us to uncover the importance of the more intangible types of capital, such as the gender of the household head, in contributing to a household's adaptive capacity. That poorer, female-headed households are more vulnerable is well known. However, understanding that they are additionally on the edges of a community's social networks has implications for development interventions, which may need to focus on how to strengthen the exchange ties of vulnerable households to enhance their sustainability in the face of both internal and external stresses and shocks. This study provides a useful baseline against which future assessments can measure the change in these social networks and ascertain whether households with greater current adaptive capacity were able to persist, compared to households with both weak connectivity and resilience. In future work, we will investigate the extent to which spatial location and kinship play a role in shaping these exchange networks.

Responses to this article can be read online at:

http://www.ecologyandsociety.org/issues/responses. php/4963

\section{Acknowledgments:}

We would like to thank the community of Habu for giving us their time and information, with no obvious or immediate benefit to them. We would also like to thank Chris McCarthy, University of Florida, for all his assistance with the social network analysis, and to Jane Southworth, University of Florida, for supporting this research through the NASA grant NNX09AI25G: "Understanding and predicting the impact of climate variability and climate change on land use and land cover change via socio-economic institutions in southern Africa."

\section{LITERATURE CITED}

Adger, W. 2003. Social capital, collective action, and adaptation to climate change. Economic Geography 79 (4):387-404.

Adger, W. N. 2000. Social and ecological resilience: are they related? Progress in Human Geography 24(3):347-364.

Adger, W. N., N. Brooks, G. Bentham, M. Agnew, and S. Eriksen. 2004. New indicators of vulnerability and adaptive capacity. Tyndall Centre for Climate Change Research, University of East Anglia, Norwich, Norfolk, UK.

Alcorn, J., and V. Toledo. 1998. Resilient resource management in Mexico's forest ecosystems: the contribution of property rights. Pages 216-249 in F. Berkes and C. Folke, editors. Linking social and ecological systems. Cambridge University Press, Cambridge, UK.

Anderies, J. M., B. Walker, and A. Kinzig. 2006. Fifteen weddings and a funeral: case studies and resilience-based management. Ecology and Society 11 (1):21. [online] URL: http://www.ecologyandsociety.org/vol11/iss1/art21/

Bauer, S., and I. Scholz. 2010. Adaptation to climate change in southern Africa: new boundaries for sustainable development? Climate and Development 2(2):83-93. http:// dx.doi.org/10.3763/cdev.2010.0040

Bendsen, H., and H. Gelmroth. 1983. Land use planning: Ngamiland Communal First Development Area: final report. Ministry of Local Government, Lands and Housing, Gabarone, Botswana.

Berkes, F., and C. Folke, editors. 1998. Linking social and ecological systems: management practices and social mechanisms for building resilience. Cambridge University Press, Cambridge, UK.

Blaikie, P. 2006. Is small really beautiful? Community-based natural resource management in Malawi and Botswana. World Development 34(11):1942-1957. http://dx.doi.org/10.1016/j. worlddev.2005.11.023 
Blaikie, P., T. Cannon, I. Davis, and B. Wisner. 1994. At risknatural hazards, peoples vulnerability and disasters. Routledge, London, UK.

Bodin, Ö., B. Crona, and H. Ernstson. 2006. Social networks in natural resource management: what is there to learn from a structural perspective? Ecology and Society 11 (2):r2. [online] URL: http://www.ecologyandsociety.org/vol11/iss2/resp2/

Borgatti, S., M. Everett, and L. Freeman. 2002. UCINET for Windows: software for social network analysis. Analytic Technologies, Harvard, Massachusetts, USA.

Brass, D. J. 1984. Being in the right place: a structural analysis of individual influence in an organization. Administrative Science Quarterly 29:518-539. http://dx.doi.org/10.2307/2392937

Brooks, N., and W. N. Adger. 2005. Assessing and enhancing adaptive capacity. Pages 165-181 in B. Lim and E. SpangerSiegfried, editors. Adaptation policy frameworks for climate change: developing strategies, policies and measures. UNDPGEF, Cambridge University Press, Cambridge, UK.

Busby, J. W., T. D. Smith, K. L. White, and S. M. Strange. 2010. Locating climate insecurity: where are the most vulnerable places in Africa? Robert S. Strauss Center for International Security and Law, University of Texas, Austin, Texas, USA.

Carney, D., M. Drinkwater, T. Rusinow, K. Neefjes, S. Wanmali, and N. Singh. 1999. Livelihoods approaches compared. Department for International Development (DFID), London, UK.

Carpenter, S. R., B. Walker, J. M. Anderies, and N. Abel. 2001. From metaphor to measurement: resilience of what to what? Ecosystems 4:765-781.

Cassidy, L. 2000. CBNRM and legal rights to resources in Botswana. SNV/IUCN CBNRM Support Programme, Gabarone, Botswana.

Cassidy, L. 2003. Anthropogenic burning in the Okavango panhandle of Botswana: livelihoods and spatial dimensions. Thesis. University of Florida, Gainesville, Florida, USA.

Central Statistics Office. 2002. Population of towns, villages and associated localities in August 2001. Government of Botswana, Gaborone, Botswana.

Chambers, R., and G Conway. 1992. Sustainable rural livelihoods: practical concepts for the $21^{\text {st }}$ century. Institute of Development Studies, University of Sussex, Brighton, UK.

Crona, B., and Ö. Bodin. 2006. What you know is who you know: communication patterns among resource users as a prerequisite for co-management Ecology and Society 11 (2):7. [online] URL: http://www.ecologyandsociety.org/vol11/iss2/ art7/
Dershem, L., and D. Gzirishvili. 1998. Informal social support networks and household vulnerability: empirical findings from Georgia. World Development 26(10):1827-1838. http:// dx.doi.org/10.1016/S0305-750X(98)00085-0

Ellis, F. 2000. Rural livelihoods and diversity in developing countries. Oxford University Press, Oxford, UK.

Food, Agriculture and Natural Resources Policy Analysis Network (FANRPAN). 2006. Developing a statistical index - the Household Vulnerability Index (HVI)_for quantifying vulnerability as a means of improving targeting of impact responses. [online] URL: http://www.fanrpan.org/documents/ d00134/

Folke, C., J. Colding, and F. Berkes. 2003. Synthesis: building resilience and adaptive capacity in social-ecological systems. Pages 352-387 in F. Berkes, J. Colding, and C. Folke, editors. Navigating social-ecological systems-building resilience for complexity and change. Cambridge University Press, Cambridge, UK. http://dx.doi.org/10.1017/CBO9780511541957.020

Goh, K. I., E. Oh, B. Kahng, and D. Kim. 2003. Betweenness centrality correlation in social networks. Physical Review E 67(1):017101. http://dx.doi.org/10.1103/PhysRevE.67.017101

Gunderson, L. H. 2000 Ecological resilience-in theory and application. Annual Review of Ecology, Evolution and Systematics 31:425-439.

Gunderson, L H., and C. S. Holling, editors. 2002. Panarchy: understanding transformations in human and natural systems. Island Press, Washington, D.C., USA.

Hahn, M. B., A. M. Riederer, and S. O. Foster. 2009. The Livelihood Vulnerability Index: a pragmatic approach to assessing risks from climate variability and change. A case study in Mozambique. Global Environmental Change 19 (1):74-88. http://dx.doi.org/10.1016/j.gloenvcha.2008.11.002

Hanneman, R., and M. Riddle. 2005. Introduction to social network methods. University of California, Riverside, California, USA.

Heijmans, A. 2004. From vulnerability to empowerment. Pages 115-127 in G. Bankoff, G. Frerks, and D. Hilhorst, editors. Mapping vulnerability: disasters development and people. Earthscan, London, UK.

Holland, J. H. 1995. Hidden order: how adaptation builds complexity. Helix, Reading, Massachusetts, USA.

Holling, C. S. 2001. Understanding the complexity of economic, ecological, and social systems Ecosystems 4:390405 .

Janssen, M., Ö. J. Bodin, T. Anderies, H. Elmqvist, H. Ernstson, R. McAllister, P. Olsson, and P. Ryan. 2006. Toward a network perspective of the study of resilience in social- 
ecological systems. Ecology and Society 11(1): 15. [online] URL: http://www.ecologyandsociety.org/vol11/iss1/art15/

Kgathi, D. L., and M. R. Motsholapheko. 2011. Livelihood activities and income portfolios in rural areas of the Okavango Delta, Botswana. Pages 35-54 in D. L. Kgathi, B. N. Ngwenya, and M. B. K. Darkoh, editors. Rural livelihoods, risk and political economy of access to natural resources in the Okavango Delta, Botswana. Nova, New York, New York, USA.

Kgathi, D. L., B. N. Ngwenya, and J. Wilk. 2007. Shocks and rural livelihoods in the Okavango Delta, Botswana. Development Southern Africa 24 (2):289-308. http://dx.doi. org/10.1080/03768350701327186

Levin, S. 1999. Fragile dominion: complexity and the commons. Helix, Reading, Massachusetts, USA.

Lhotka, L., C. Bailey, and M. Dubois. 2008. Ideologically structured information exchange among environmental groups. Rural Sociology 73 (2):230-249.

Manyena, S. B. 2006. The concept of resilience revisited. Disasters 40(3):433-450. http://dx.doi.org/10.1111/ j.0361-3666.2006.00331.x

Mbaiwa, J. E., A. Stronza, and U. Kreuter. 2011. From collaboration to conservation: insights from the Okavango Delta, Botswana. Society and Natural Resources 24(4):400411. http://dx.doi.org/10.1080/08941921003716745

McCarty, C., P. Killworth, and J. Rennell. 2007. Impact of methods for reducing respondent burden on personal network structural measures. Social Networks 29 (2):300-315. http:// dx.doi.org/10.1016/j.socnet.2006.12.005

Morton, J. F. 2007. The impact of climate change on smallholder and subsistence agriculture. Proceedings of the National Academy of Sciences 104(50):19680. http://dx.doi. org/10.1073/pnas.0701855104

Nelson, D., W. Adger, and K. Brown. 2007. Adaptation to environmental change: contributions of a resilience framework. Annual Review of Environment and Resources 32:395-419. http://dx.doi.org/10.1146/annurev. energy.32.051807.090348

Olsson, P., C. Folke, and F. Berkes. 2004. Adaptive comanagement for building resilience in social-ecological systems. Environmental Management 34(1):75-90. http://dx. doi.org/10.1007/s00267-003-0101-7

Pacheco, P. 2009. Smallholder livelihoods, wealth and deforestation in the eastern Amazon. Human Ecology 37 (1):27-41. http://dx.doi.org/10.1007/s10745-009-9220-y

Perz, S. 2005. The importance of household asset diversity for livelihood diversity and welfare among small farm colonists in the Amazon. The Journal of Development Studies 41 (7):1193-1220. http://dx.doi.org/10.1080/00220380500170899

Putnam, R. D. 2001. Bowling alone: the collapse and revival of American community. Simon and Schuster, New York, New York, USA.

Regional Climate Change Programme. 2009. Problem areas and hotspots in Botswana. UK Aid, Department for International Development (DFID), London, UK. [online] URL: http://www.rccp.org.za/index.php?option=com content\&view= category \&layout $=$ blog $\& \mathrm{id}=61 \&$ goto $=$ top $\&$ Itemid $=68 \&$ lang $=$ en\#top

Sagar, A. D., and A. Najam. 1998. The human development index: a critical review. Ecological Economics 25(3):249264. http://dx.doi.org/10.1016/S0921-8009(97)00168-7

Sallu, S., C. Twyman, and D. Thomas. 2009. The multidimensional nature of biodiversity and social dynamics and implications for contemporary rural livelihoods in remote Kalahari settlements, Botswana. African Journal of Ecology 47:110-118. http://dx.doi.org/10.1111/j.1365-2028.2008.01057. $\underline{\mathrm{x}}$

Sallu, S. M., C. Twyman, and L. C. Stringer. 2010. Resilient or vulnerable livelihoods? Assessing livelihood dynamics and trajectories in rural Botswana. Ecology and Society 15(4): 3. [online] URL: http://www.ecologyandsociety.org/vol15/iss4/ $\underline{\operatorname{art} 3 /}$

Scoones, I. 1998. Sustainable rural livelihoods: a framework for analysis. IDS Brighton, Brighton, UK.

Shackleton, C. M., and S. E. Shackleton. 2006. Household wealth status and natural resource use in the Kat River Valley, South Africa. Ecological Economics 57 (2):306-317. http:// dx.doi.org/10.1016/j.ecolecon.2005.04.011

Shackleton, C. M., S. E. Shackleton, and B. Cousins. 2001. The role of land-based strategies in rural livelihoods: the contribution of arable production, animal husbandry and natural resource harvesting in communal areas in South Africa. Development Southern Africa 18(5):581-604. http://dx.doi. org/10.1080/03768350120097441

Slocum, R., L. Wichhart, D. Rocheleau, and B. ThomasSlayter, editors. 1998. Power, process and participationtools for change. Intermediate Technology, London, UK.

Thomalla, F., T. Downing, E. Spanger-Siegfried, G. Han, and J. Rockström. 2006. Reducing hazard vulnerability: towards a common approach between disaster risk reduction and climate adaptation. Disasters 30(1):39-48. http://dx.doi. org/10.1111/j.1467-9523.2006.00305.x

Tlou, T. 1976. The peopling of the Okavango Delta c. 17501906. Pages 49-53 in Proceedings of the Symposium on the 
Okavango Delta and its Future Utilisation. Botswana Society, National Museum, Gaborone, Botswana.

Twigg, J. 2007. Characteristics of a disaster-resilient community. A guidance note. DFID Disaster Risk Reduction Interagency Coordination Group, London, UK.

Twyman, C. 2000. Livelihood opportunity and diversity in Kalahari wildlife management areas, Botswana: rethinking community resource management. Journal of Southern African Studies 26(4):783-806. http://dx.doi.org/10.1080/713683606

Twyman, C. 2001. Natural resource use and livelihoods in Botswana's Wildlife Management Areas. Applied Geography 21:45-68. http://dx.doi.org/10.1016/S0143-6228(00)00016-3

Valente, T. W., and R. K. Foreman. 1998. Integration and radiality: measuring the extent of an individual's connectedness and reachability in a network. Social Networks 20(1):89-105. http://dx.doi.org/10.1016/S0378-8733(97)00007-5

Vemuri, A. W., and R. Costanza. 2006. The role of human, social, built, and natural capital in explaining life satisfaction at the country level: toward a National Well-being index (NWI). Ecological Economics 58(1):119-133. http://dx.doi. org/10.1016/j.ecolecon.2005.02.008

Vincent, K. 2007. Uncertainty in adaptive capacity and the importance of scale. Global Environmental Change 17(1):1224. http://dx.doi.org/10.1016/j.gloenvcha.2006.11.009

Walker, B. H., and D. A. Salt. 2006. Resilience thinking: sustaining ecosystems and people in a changing world. Island Press, Washington, D.C., USA.

Webb, C., and O. Bodin. 2008. A network perspective on modularity and control of flow in robust systems. Pages 85118 in J. Norberg and G. Cumming, editors. Complexity theory for a sustainable future. Columbia Press, Chichester, New York, USA.

Wilk, J., and D. L. Kgathi. 2007. Risk in the Okavango Delta in the face of social and environmental change. Geojournal 70:121-132. http://dx.doi.org/10.1007/s10708-008-9119-y 